\title{
SOP Model Based on Employment Instruction from EMI Results to Improve the Satisfaction of Higher Education Service
}

\author{
Sri Uchtiawati ${ }^{1}$ \\ ${ }^{1}$ Mathematics Education, University of Muhammadiyah Gresik, Indonesia \\ Correspondence: Sri Uchtiawati, Lecturer of Mathematics Education, University of Muhammadiyah Gresik, \\ Indonesia.
}

Received: December 11, 2017

Accepted: January 25, 2018

Online Published: January 31, 2018

doi:10.20849/aes.v3i1.299

URL: https://doi.org/10.20849/aes.v3i1.299

\begin{abstract}
This study aim for analyze satisfaction Higher education service which is a form of servant performed by managers to stakeholders, based on Internal Quality Evaluation (EMI) result, from EMI achievement, set the Standard Operational Procedure and Work Instruction model, given the satisfaction of service is a very important part. The research method is correlation with the indicator consist of standard of Content, Process, Competence of graduates, Educator and educational staff, Facilities and infrastructure of Education, Management of Prodi, Financing, Assessment, Research and Community Service, then, from EMI standard, correlated with stakeholders' satisfaction, with satisfaction level determined by category (a) satisfactory, if Expected Service/ES = Perceived Service (PS), (b) is not satisfactory when perceived service is lower than expectation (ES $\geq$ PS) and (c) very satisfying/happy when the service is perceived to exceed expectations (PS $\geq E S$ ), and then performed data analysis. To define the model using several stages of the 4-D model include stages, definitions, design, development, and use or application. The result of correlation on study program A and study program B and Islamic education are different, for study program A is Competency Standard of Graduates (X3) with regression coefficient $\mathrm{b} 3=0,076$ and correlation coefficient $\mathrm{R} 3=0,186$, while study program $\mathrm{B}$ is Graduate Competency Standard $\left(\mathrm{X}_{3}\right)$ with regression coefficient $b_{3}=0,138$ with correlation coefficient $R_{3}=0,183$, while indicator education according to government's provision, which has correlation level at graduate level. The results of this research become the basis in determining SOP Model and Work Instruction, which then tested at universities studied, and in general the application of this model is in the category of Satisfactory.
\end{abstract}

Keywords: stakeholders' satisfaction, EMI

\section{Introduction}

Quality and satisfactory service performed by service managers, especially on education services is a demand for stakeholders. While the purpose of education services is the provision of the manager of both the goods produced and the services offered, in order to gain interest from users of services and consumers, the service may affect the interests or desires of the user or consumer of a good or service offered and an important factor required. For managers in the field of service, service quality is a very important factor, because in marketing service products, interaction between producers and consumers occur directly. Application of service quality as the nature of product appearance or performance is one of the main part of strategic $i$ that must be done by the service manager, especially education service. Furthermore, to achieve sustainable excellence service services should pay attention to quality, which is a benchmark on customer satisfaction or stakeholders. As an illustration of the relationship between service and satisfaction as written by some experts who discuss about the quality that service quality and meet customer satisfaction consists of three basic components that must be understood for each service provider that is: (1). Preliminary activity which is a process or activity stages conducted on the activities before the sale where at this stage service providers and managers have the opportunity to establish relationships with stakeholders this activity can be done by informing the product to consumers and create confidence in the consumer for the products offered. (2). Is a process during the transaction where in this phase service providers must still maintain the quality of service, so that consumers remain a loyal customer. Communication in this phase is very important, because in this phase consumers need more information will be purchased products so that if the company does not understand about the products offered consumers could switch to other companies. (3). Post-sales process, in the following stages for service providers are expected to 
pay attention and be able to respond to problems of the parties of facilities that have been given to stakeholders, these three things become a consideration for service users in receiving services from an institution. To understand the quality of services, one of the policies that the managers do is to determine the Internal Quality Evaluation (EMI), in this research applied in the Education Institute of Power Personnel, the results of these achievements are reviewed on standards that can affect student satisfaction categorized as stakeholders, and to ensure a quality service flow, the Standard Operational Procedure Model is established, and is supported by Work Instructions.

Educational Services is a service that basically services are having unique characteristics that distinguish it from goods or manufactured products. To distinguish it, there are four characteristics most often encountered in the service and differentiator of the goods in general as in various views among them (Tjiptono, 1998), (Berry, 1995), (Bove, 1995), that the character that becomes the benchmark are: Intangibility, Inseparability, Variability, and Perishability, thus, in general can be interpreted that; (1) Service is an action, intangible meaning Services are abstract, cannot be seen, felt, tasted or touched as can be felt from a good. (2) Heteregonitas, is very variable, that is Service is non-standard variable and highly variable. That is, because the service is in the form of a performance, then there is no result of the same service even if done by one person. This is due to human interaction (employees and managers and users of services) with all the different expectations and perceptions that accompany the interaction. (3) Cannot be separated Services are generally produced and consumed at the same time, with consumer participation in the process. Indicating the consumer must be in the place of service he requested, so that consumers see and can even take part in the process of it. (4) Not durable Service may not be stored in inventory, it can be said, services cannot be saved, resold to others, or returned to the service producer where he purchased the services. In the discussion of education services in the service process required the quality, or quality which means that Quality is often one of the benchmarks of customer satisfaction or conformance to the requirements. For discussion of satisfaction, then some other views are stated that the level of satisfaction, there are five main factors that must be considered and done by the company, as well as managers of services, namely: (1) Quality of results as outcome, customers will feel satisfied if their evaluation results indicate that the products they use quality as expected. (2) Quality of service; especially for the service industry, customers will feel satisfied if they get a good service or as expected. (3) Emotionally, service users will feel proud and gain confidence that others will be amazed by it when using products with a certain quality status that tend to have higher levels of satisfaction, these three include result mechanisms and processes that hope to gain satisfaction, obtained not because of the quality of the product but the social value or self-esteem that makes the customer satisfied with a particular brand. (4) Prices, products of the same quality but set a relatively cheap price will give higher value to its customers. (5) Costs, Customers do not need to incur additional costs or do not need to waste time to get a product or service tend to be satisfied with the product or service. Furthermore, on the other hand stakeholders or users of services, especially in the field of education will pay attention to the quality of services such as proposed by Garvin (in Lovelock.1994) i.e. dimensions of service quality at least comprise performance (performance), excess product (feature) durability (durability), features (feature), reliability / trustworthy (reliability), suitability to the specifications (conformance to specification), durability (durability), speed and comfort (serviceability) attractiveness (aesthetics) and quality are prepared (perceived quality). A view of the quality of these services is basically applicable in the field of education, so that the indicators are emphasized to be a basic part of service quality.

Customer satisfaction: a goal to be achieved by education service managers, from users in using services to maximize total satisfaction, according to economists' point of view, calls this total satisfaction a total utility of consumers acquired when consume a product. This is due to the quality of focusing on customer satisfaction, so it is necessary to understand the components associated with customer satisfaction. Basically consumer satisfaction can be defined simply as a condition where the needs, wants, and expectations of consumers can be met through services provided by the manager. Consumer satisfaction is the main goal to be achieved by the provider services. because consumer satisfaction greatly influences consumer decisions whether the consumer will reuse the service or not, and whether the consumer will decide to buy the last time or decide to become a customer (Gaspersz, 2003).Stakeholder satisfaction is an evaluation that has been done by providing services, where the chosen alternatives at least give outcomes equal or exceed expectations, while dissatisfaction occurs when the results obtained do not meet expectations.

Internal Quality Evaluation (EMI) is one of the activities to evaluate the quality applied to the higher education service with the following implementation flow: 


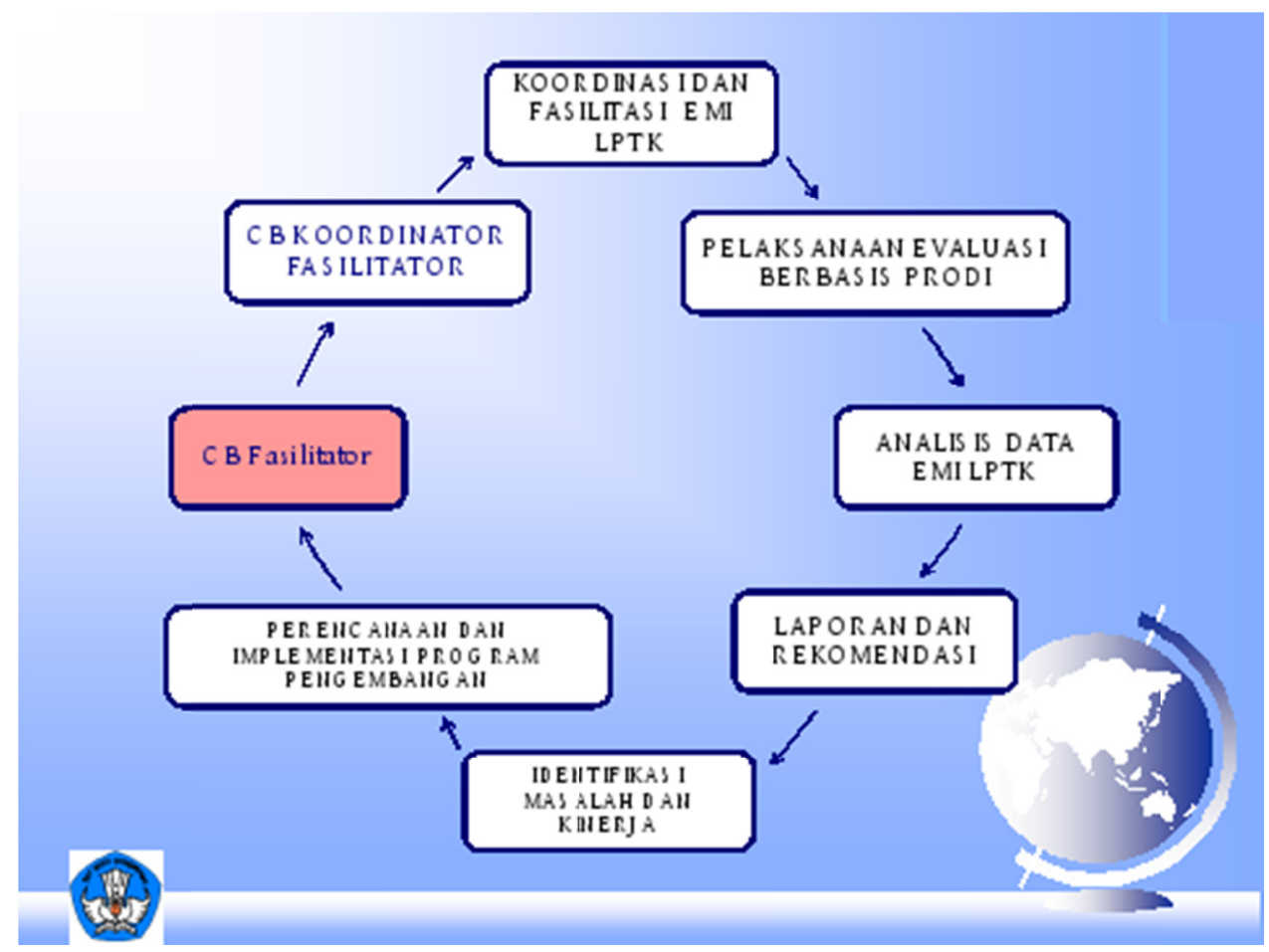

Figure 1. EMI LPTK implementation flows

Source: Human Resource Development Board Education and Culture and Quality Assurance of Education

This flow shows that quality is a very complex concept and can be a special attraction for the user, although it is difficult to categorize what exactly the meaning of quality itself is definitely, in the business sphere as written Lloyd Dobbins and Clare Crawford-Mason "... Quality is the feeling of appreciation that something is better than the other (1996: 210) to find a quality category, then the term evaluation which is literally said Evaluation of (English: Evaluation ) means the process of assessment, while in the field of education, evaluation can defined as a process of measurement carried out through a strategy used in an effort to achieve the objectives that have been set, and service can be qualified if: meet 4 things: quality input, process, output, and outcome, namely: (1). Educational input is considered qualified if it has been processed. (2). Quality education process if able to create an atmosphere that active, creative and also fun, (3). Output declared quality if result learn in academic and non-academic student high, (4).Outcome is declared qualified if graduates are quickly absorbed in the world of work, a reasonable salary, and all parties recognize the greatness of their graduates and are satisfied.

If done a comparison then do the measurement as a result of quality evaluation in the field of services with the quality of goods, then the assessment of service quality is more complex and more difficult. This is due to the use of services, tangible cues are relatively limited, and preferably tend to be in the physical form (building) equipment and personnel as service personnel. Measuring the quality of services in the field of education means evaluating comparing the management of a service with a number of predefined standards and in this study is the standard of the National Education Standards Agency (BSNP) which sets minimum criteria on the education system throughout the jurisdiction of the unitary state of the Republic of Indonesia, which is an independent, professional, and independent body that carries out a mission to develop, monitor implementation and evaluate the implementation of the National Education Standards, while the standards applied at Higher education through EMI include 10 standards, comprising National Education Standards and supplemented Standards of Research, and Standards of Community Service.(Act No.12 of 2012)

Quality that can be measured through an evaluation, will be able to provide the level of satisfaction, which In general understanding consumer satisfaction or consumer dissatisfaction is the difference between expectations (expectations) and perceived performance (perceived performance).So it can be said that customer satisfaction means the performance of a good / service at least the same as expected. Kotler (2000: 36) suggests that the level of satisfaction is: Satisfaction is a person's feelings of pleasure or disappointment resulting from comparing a product's perceived performance (or outcome) in relation to his or her expectations. " 
From the quality of service to be able to determine the satisfaction in the field of education, then how the management of a college, will provide a; satisfaction or dissatisfaction, for the user of the service, because in the management will produce a product, and how the product produced by the college, then some opinions that have expressed it, such as; as stated by Ndraha (1988: 65) there are at least two kinds of products from universities, namely "(a) the added value of human being obtained by students, so that he is expected to be ready to enter the real world and the people included in this category are the determination and transformation of values, this category is a college product as an educational process and a judgment process, (b) scientific discoveries and technological innovation that makes college products a process ".

Standard Operational Procedure, defined as a mechanism to form a path to be followed, in order to achieve goals, to meet stakeholders' satisfaction, with clarity narrated through Work Instructions. SOPs can also be used as guidelines or references for performing job tasks in accordance with the functions of each work unit, up to the Institution, and SOP is also a tool for assessing the achievement of performance procedures, based on technical, administrative and procedural indicators in accordance with work procedures, procedures and working system of the work unit concerned.

\section{Methods}

This study is conducted through two stages, firstly done correlation research, to know the relation between measurable EMI application in achievement value of each standard with stakeholder satisfaction, and secondly done research of development of Model to determine SOP based on work instruction, technical data collection using primary data and secondary data, using questionnaire, observation and then tested. To set the development model SOP-based instructions for this work through the stages of use cycles customized field conditions, with predictions of two (2) rounds are based on test results to stakeholders namely students as users of the service, then socialized at the college researched conducting seminars and expert validation, and validating the data, then analyzing again, revising and final stage until determined SOP model, along with standard work instructions, to be applied to LPTK/Faculty of Teacher Training and Education / Faculty of Education in Higher Education of Gresik Regency. The model of S OP that has been developed is further tested on the students as stakeholders, while the satisfaction of the determination is based on the high of the difference between the expectation and the perception of the students on the service of the college, the gap between expectation and the student's perception will determine that the quality of education services can be said ) satisfactory, if Expected Service / ES = Perceived Service (PS), (b) not satisfactory / disappointing when perceived services are lower than expectations $(E S \geq P S)$ and (c) are highly satisfactory when service is perceived to exceed expectations $(P S \geq E S)$. The analysis of satisfaction levels include: determine the maximum score with the calculation of the number of validators in each assessment $\mathrm{x}$ maximum weight or $\Sigma$ maximum score $=\operatorname{nxp}=$ (Description: $n=$ number of validator, $p=$ maximum score). For the determination of rating result done calculation by formula:
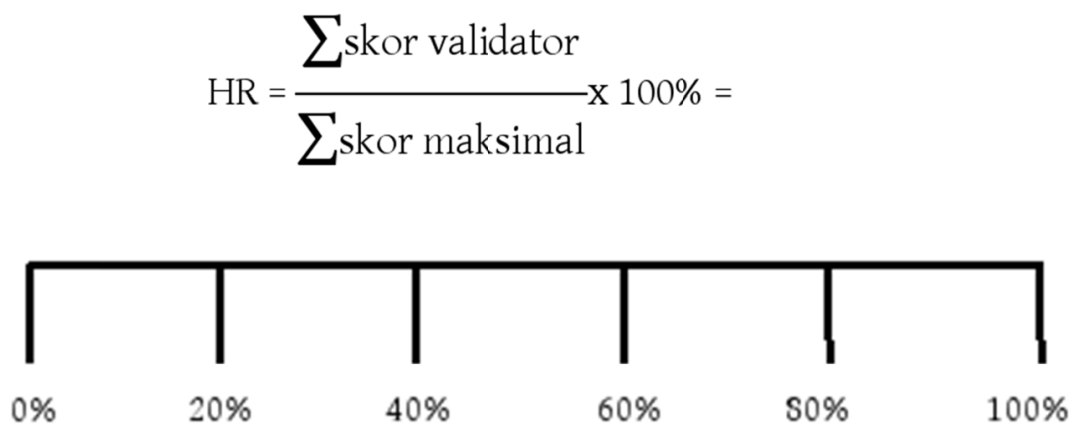

Table 1. Percentage score, with description

\begin{tabular}{cc}
\hline Interval & Criteria \\
\hline $0 \%-20 \%$ & Very unfeasible \\
$21 \%-40 \%$ & Quite unfeasible \\
$41 \%-60 \%$ & Feasible enough \\
$61 \%-80 \%$ & Quite feasible \\
$81 \%-100 \%$ & Very feasible \\
\hline
\end{tabular}




\section{Results and Discussion}

This research was conducted at University of Gresik that held Internal Quality Evaluation (EMI), for Faculty of Teacher Training Education and Islamic High School at Faculty of Islamic Religion by completing EMIS. The Quality Evaluation applied in this university has a different specification, between EMI and EMIS. The achievement value of EMI obtained are:

Table 2. Value achievement of EMI Prodi mathematics education

\begin{tabular}{lll}
\hline Weighted average & 78.78 & Good \\
\hline
\end{tabular}

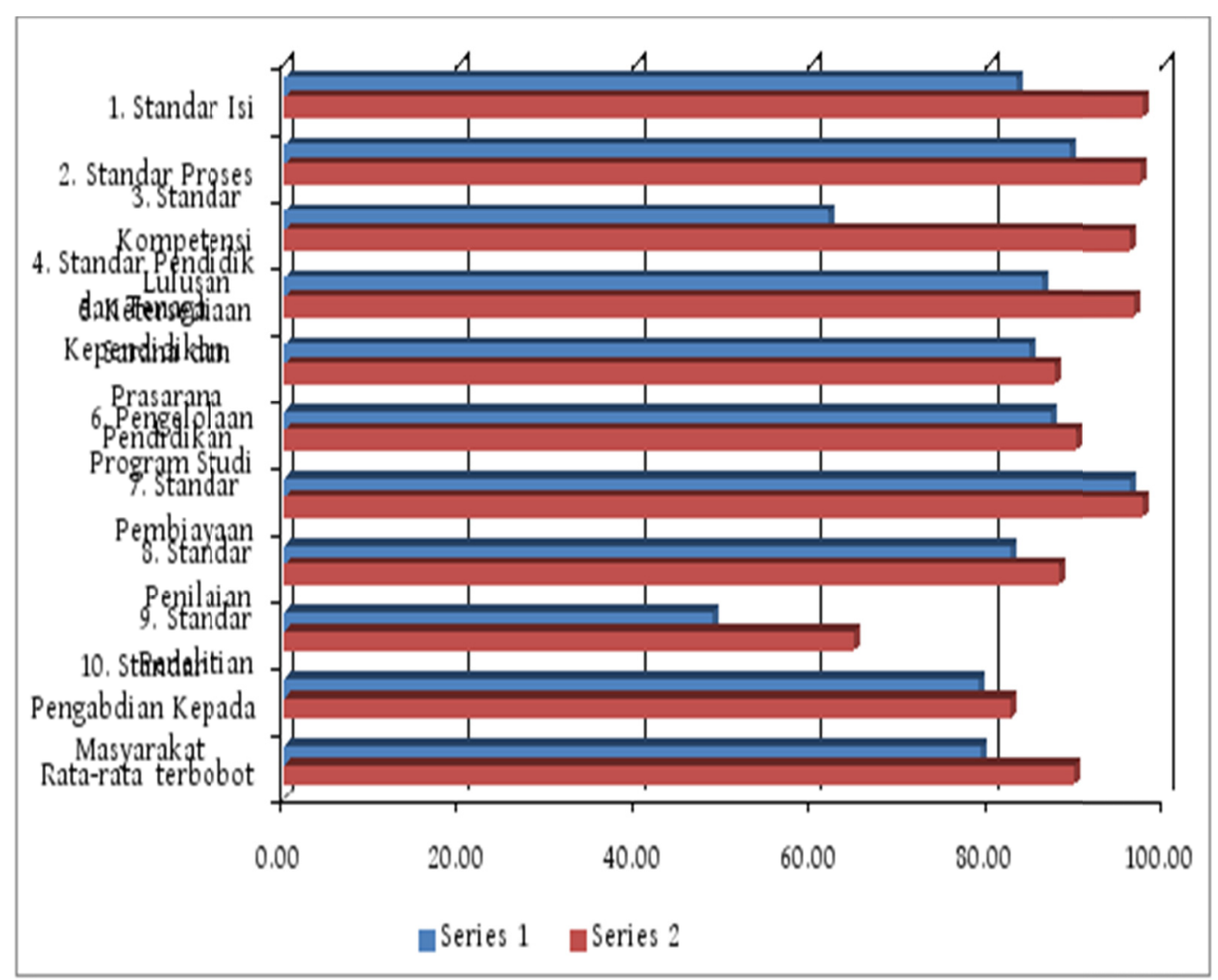

Figure 2. Graph of EMI achievement

Source: Document Result of EMI Prodi "A"

At Prodi A it obtained results of Achievement standard EMI which consists of 10 standards that affect the student satisfaction are: 1) Standards for Content $\left.\left(X_{1}\right), 2\right)$ Processing Standards $\left(X_{2}\right)$, 3) Competency Standards Graduates $\left.\left(X_{3}\right), 4\right)$ Education Infrastructure Standards $\left(X_{5}\right)$, and 5) Research Standards $\left(X_{9}\right)$.

Achievements of EMI standards that have no effect on the satisfaction of students are: 1) Education and Teaching Staff Standards $\left.\left(X_{4}\right), 2\right)$ Management Standards Prodi $\left.\left(X_{6}\right), 3\right)$ Financing Standards $\left.\left(X_{7}\right), 4\right)$ Assessment Standards $\left(X_{8}\right)$, and 5) Standard of Community Service $\left(X_{10}\right)$. By calculation:

Table 3. Model summary

\begin{tabular}{ccccc}
\hline Model & R & R Square & Adjusted R Square & Std. Error of the Estimate \\
\hline 1 & $.082(\mathrm{a})$ & .007 & .007 & .996 \\
\hline
\end{tabular}

a. Predictors: (Constant), $\mathrm{x}$ 
Table 4. ANOVA (b)

\begin{tabular}{llrrrrr}
\hline Model & & Sum of Squares & \multicolumn{1}{c}{ df } & Mean Square & F & Sig. \\
\hline 1 & Regression & 53.591 & 1 & 53.591 & 54.046 & (A) \\
& Residual & 7996.048 & 8064 & .992 & & \\
& Total & 8049638 & 8065 & & & \\
\hline
\end{tabular}

a. Predictors: (Constant), $\mathrm{x}$

b. Dependent Variable: $y$

Table 5. Coefficients (a)

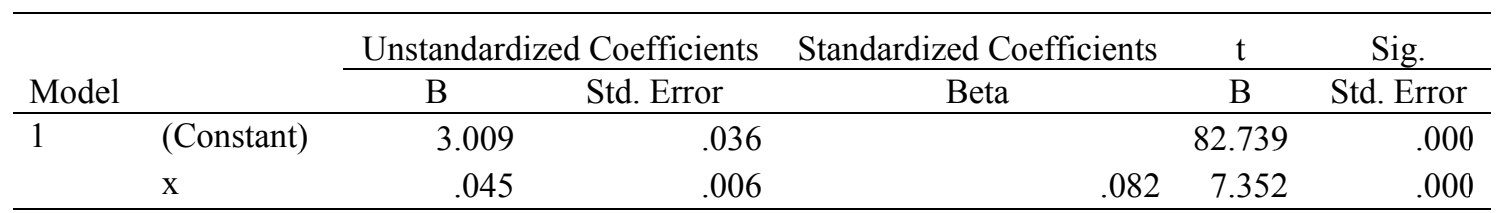

a Dependent Variable: $y$

Things that can be seen from Print Out, among others:

a. The regression equation $Y$ over $X: \quad \hat{Y}=3,009+0,045 \times$ (Table Coefficients)

b. From the ANOVA table, obtained P-value (sig) $=0,000<a=0,05$, then Ho is rejected. This means that there is influence between EMI $(X)$ Achievement on Student Satisfaction $(Y)$ at 0.05 significance level.

c. Significant test of regression coefficient is obtained, P-value (sig) $=0,000<a=0,05$, then Ho is rejected or significant regression coefficient $b$ (Table Coefficients).This means that the variable $X$ significantly affects the variable $Y$ at the 0.05 significance level.

$\mathrm{d}_{R^{2}}$ The correlation coefficient $R=0.082$, including very low, while the coefficient of determination $R^{2}=0.006$ (table Model Summary). Meaning: about $0 \%$ variable $X$ affect the change of variable $Y$, the remaining $100 \%$ influenced by other variables that are not explained.

Table 6. Value achievement of EMI prodi "B"

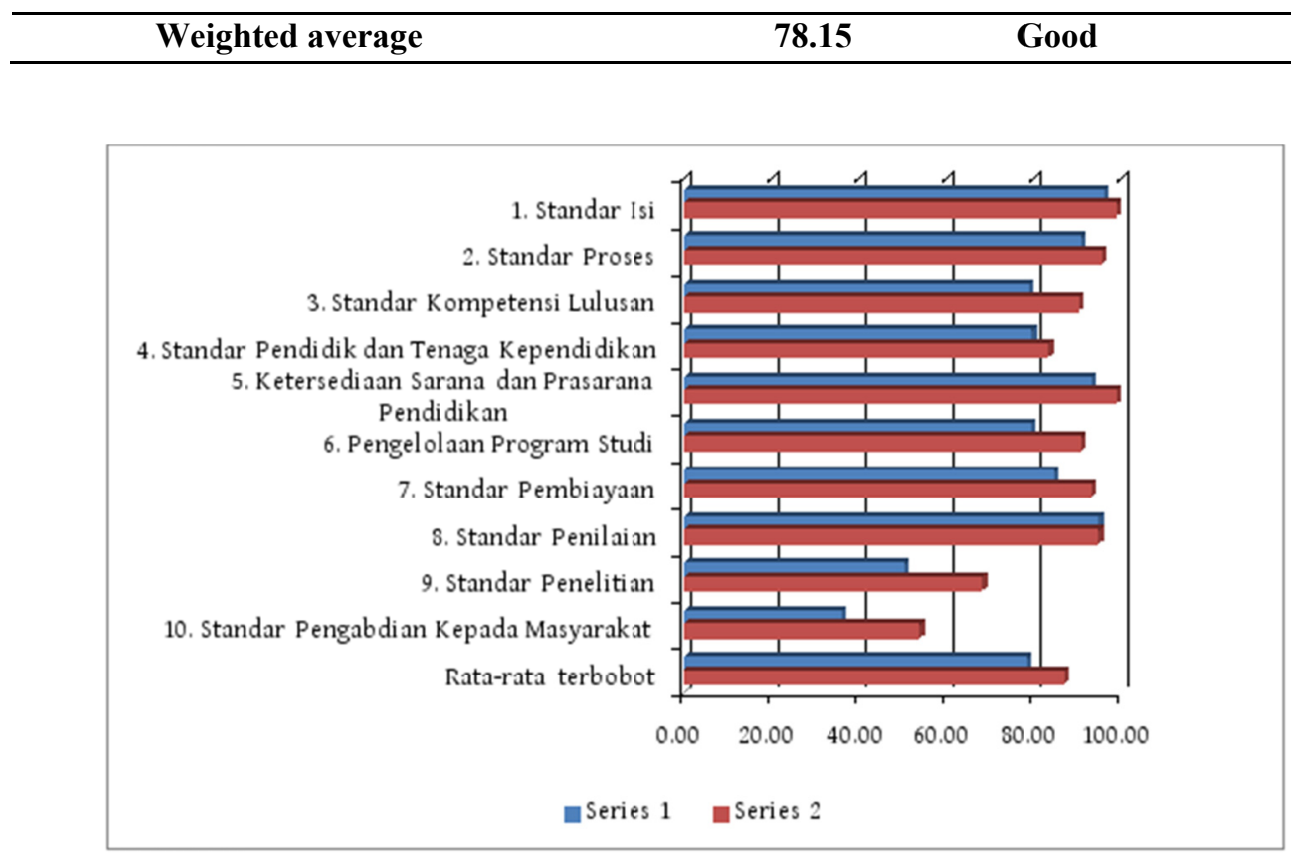

Figure 3. Graph of EMI achievement

Source: Document Result of EMI Prodi B 
In Prodi B, the achievement of EMI standard on student satisfaction are: 1) Graduate Competency Standard $\left(\mathrm{X}_{3}\right)$, 2) Education Standard and Education Personnel $\left(X_{4}\right)$, and 3) Education Infrastructure Standards $\left(X_{5}\right)$.

The achievements of EMI standards that have no effect on the satisfaction of students are: 1) Content Standards $\left.\left(X_{1}\right), 2\right)$ Process Standards $\left.\left(X_{2}\right), 3\right)$ Management Standards $\left.\left(X_{6}\right), 4\right)$ Financing Standards $\left.\left(X_{7}\right), 5\right)$ Assessment Standards $\left.\left(X_{8}\right), 6\right)$ Research Standards $\left(X_{9}\right)$. And 7) Standard Community Service $\left(X_{10}\right)$. By calculation.

Table 7. Model summary

\begin{tabular}{lrrrr}
\hline Model & R & R Square & Adjusted R Square & Std. Error of the Estimate \\
\hline 1 & $.064(\mathrm{a})$ & .004 & .004 & .942 \\
\hline
\end{tabular}

a Predictors: (Constant), $\mathrm{x}$

Table 8. ANOVA (b)

\begin{tabular}{llrrrrr}
\hline Model & & Sum of Squares & \multicolumn{1}{c}{ df } & Mean Square & \multicolumn{1}{c}{ F } & \multicolumn{1}{c}{ Sig. } \\
\hline 1 & Regression & 52.966 & 1 & 52.966 & 59.728 & $(\mathrm{~A})$ \\
& Residual & 13065.010 & 14733 & .887 & & \\
& Total & 13117.976 & 14734 & & & \\
\hline
\end{tabular}

a Predictors: (Constant), $\mathrm{x}$

b Dependent Variable: y

Table 9. Coefficients (a)

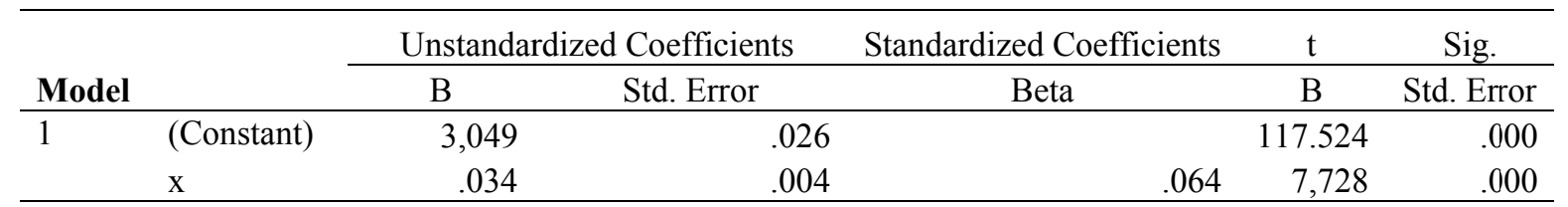

a Dependent Variable: y

Things that can be seen from Print Out, among others:

a. The regression equation $Y$ over $X: \quad Y=3,049+0,034 \times$ ( Table Coefficients)

b. From the ANOVA table, obtained P-value $(\mathrm{sig})=0,000<a=0,05$, then Ho is rejected. This means that there is influence between EMI $(X)$ Achievement on Student Satisfaction $(Y)$ at 0.05 significance level

c. Significant test of regression coefficient is obtained, P-value $(\operatorname{sig})=0,000<a=0,05$, then Ho is rejected or significant regression coefficient $b$ (Table Coefficients). This means that the variable $X$ significantly affects the variable $Y$ at the 0.05 significance level.

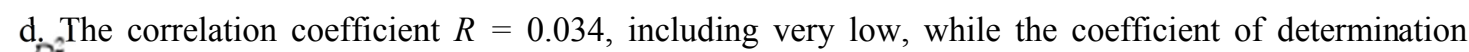
$R^{2}=0.001$ (table Model Summary). Meaning: about $0 \%$ variable $X$ affect the change of variable $Y$, the remaining $100 \%$ influenced by other variables that are not explained.

From the data analysis of both study programs, the outcomes EMI standards that most influence on student satisfaction is Graduate Competency Standards $\left(x_{3}\right)$ with a regression coefficient $b_{3}=0.138$ with a correlation coefficient $R_{3}=0.183$. And for EMIS the highest achievement that affects satisfaction is Service management, and based on the results of this research, it shows that EMI performance results influence stakeholder satisfaction, so that the SOP Model with Work Instruction is determined to ensure satisfaction of the service.

\section{Discussion}

The satisfaction of stakeholders with the achievement of EMI result shows an influence, while the target to be achieved by the education service manager, from the stakeholders as the user in using the service is to maximize the satisfaction, or (total satisfaction). From the economist's point of view, this total satisfaction is the total utility of the consumers obtained when consuming a product, while the quality focuses on customer satisfaction, 
so that the service manager needs to understand the components that are related to the consumer's satisfaction. Consumer satisfaction can be defined simply as a condition where customer needs, wants, and expectations can be met through the services provided by the manager. Considering service user satisfaction is the main objective to be achieved by the manager, it should be noted that the satisfaction is greatly affect the service user's decision to stay or not in using the service (Gaspersz, 2003).

Furthermore, stakeholders' satisfaction is an evaluation that has been done by managing services, as the chosen alternatives at least give outcomes equally or exceed expectations, whereas dissatisfaction occurs if the results obtained do not meet expectations, from this indicator high education services use EMI model as one of the activities to evaluate the quality applied to higher education services, where the word Evaluation of (English: Evaluation ) means the process of assessment, while in the field of education, evaluation can be interpreted as a process of measurement conducted through a strategy used in an effort to achieve goals has been established, and the service can be said to be quality if: it meets 4 things: quality of input, process, output, and outcome, that is: (1) Quality of education inputs have been declared in process. (2) The process of education implementation is declared qualified if able to create an atmosphere that active, creative and also fun, (3) Output declared qualified if result of learning in academic and non-academic plane high, whereas Outcome declared qualified if graduates have been processed can quickly absorbed in the world of work, a reasonable salary, able to create jobs and get recognition from the audience, the community will be the advantage of graduates made and the occurrence of a sense of satisfaction.

In the assessment of these services more complex and more difficult, this is due to several factors namely, tangible cues are relatively limited, and preferably tend to be in the form of physical (building) equipment and personnel as service personnel. As for on this study measures the quality of services in the field of education by conducting an evaluation comparing the management of a service with a number of predefined standards and is based on the provisions of the National Education Standards Agency (BSNP) with minimal criteria on education system throughout the jurisdiction of the unitary Republic of Indonesia consists of 8 standards, while the standard on EMI includes 10 standards, consisting of 8 National Standards of Education, Research Standards and Community Service Standards. (Act No.12 of 2012)

By based on standard analysis on EMI, then that is standard to the satisfaction of stakeholders defined grooves or SOP is $\mathbf{s}$ one of the important aspects in creating a Quality Assurance, so Institutions belonging to a professional, effective and efficient when applying the SOP on the entire process of organizing and Services Higher Education. This is considered important because the SOP is a guide or reference for performing job tasks in accordance with the function of each work unit, to the Institution, and SOP is also a tool of performance appraisal, based on technical, administrative and procedural indicators in accordance with work procedures, procedures and working system on the work unit concerned. With SOP set with work instruction, education in Educational / Higher Education Institution can run with definite and measured service. And in case of any form of deviation can be avoided or even if there is a deviation in the case can be found the cause and can be resolved in the appropriate way in accordance with the procedure, because it has been set in an indicator and the source of which the stipulation of the groove. Thus, if all activities in the service of this college are in accordance with the stipulated in the National Education Standards (SNP), then the implementation mechanism is set in the SOP, thus gradually the quality of service in the Institute of Education Personnel/ doing Internal Quality Evaluation (EMI) will be more professional, accurate, fast and definite. Determination of SOP Model equipped with Work Instruction, Experimental test is first performed, by analyzing the related indicators, as well as the use of language that can be influenced by stakeholders. The results of the analysis achieved in the category "very feasible" with the calculation of $94.64 \%$.

\subsection{Sample MODEL SOP with Work Instructions}

In determining the SOP of the Stakeholders Satisfaction results, based on the stages: defining, designing, development. Definition Phase, is an initial activity undertaken to review SOP at the University that perform EMI and EMIS, and then designed SOP model, from this design is analyzed based on satisfaction stakeholders to be developed as SOP Model. As for the results of the development obtained Model as follows: 
4.1.1 SOP Model for Evaluation of Achievement of Special Lessons in FKIP

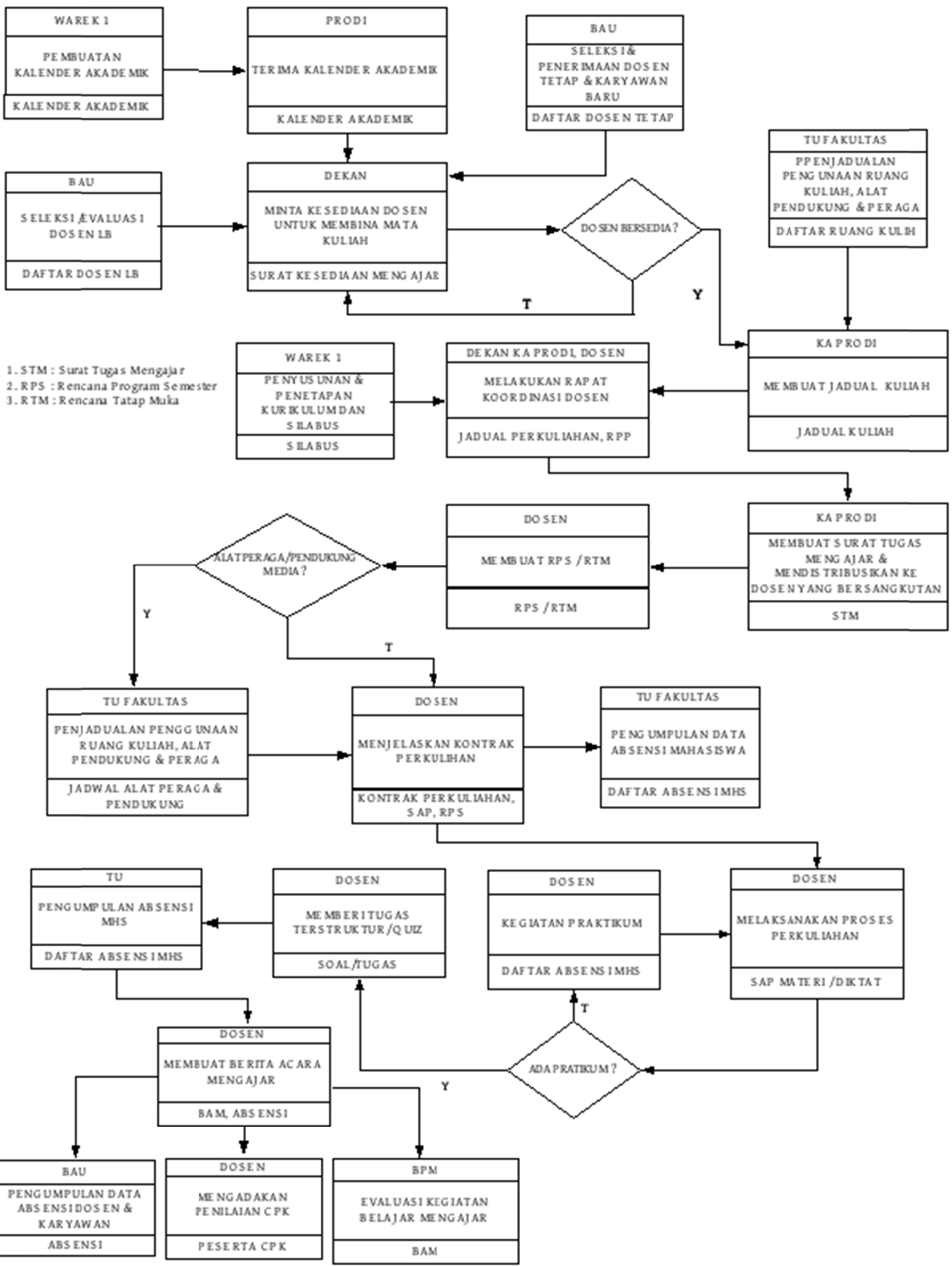

Description: This CPK Rating SOP was developed at FKIP, which was determined by involving: Vice Rector 1, Head of Department, Lecturer, Administrative Head, Head of Bureau, and completed with Work Instruction as follows 
Table 10. Work instructions achievements of special lessons (CPK)

\begin{tabular}{cccc}
\hline & LOGO of FKIP & Type of activity & Approved by \\
\hline \multirow{2}{*}{ Date set } & Created Lecturer Who & Achieving Special \\
& teach course & Lessons Learned & $\begin{array}{c}\text { head of the study } \\
\text { program }\end{array}$ \\
\hline
\end{tabular}

Aim: This procedure aims to ensure that the implementation of Special Lesson Learn goes well with; K Units of Lectures and RPS made by lecturers of course lecturers.

Scope: This procedure applies starting from the meeting preparation coordination lecturers who teach subjects up to the acceptance of the value at the end of each lecture activities Semester of lecturers who teach course

Table 11

\begin{tabular}{|c|c|c|}
\hline No. & Executor & Activities \\
\hline \multirow[t]{3}{*}{1} & Vice Rector 1 & 1. Stipulate the enactment of KKNI \\
\hline & & 2. Establish a RPS reference, and RTM (Face Plan) \\
\hline & & 3. Establish an academic calendar \\
\hline \multirow[t]{3}{*}{2} & Vice Rector 2 & $\begin{array}{l}\text { 1. Determine the cost of the examination based on the proposal of the study director } \\
\text { on each Special Lesson Study }\end{array}$ \\
\hline & & 2. Approved CPK fees in courses from the head of study program \\
\hline & & 3. Realize budget submission from the head of study program every semester. \\
\hline \multirow[t]{6}{*}{3} & Supporting & 1. Establish CPK based on curriculum \\
\hline & lecturer & 2. Performs a percentage filling activity on $\mathrm{CPK}$ \\
\hline & & 3. Make the exam in accordance with the achievement of learning \\
\hline & & 4. Conducting exams to set values on CPK \\
\hline & & 5. Charging CPK based on the results of the exam on-line \\
\hline & & 6. Submit the test result to the Head of administration both soft copy and hard copy \\
\hline \multirow[t]{5}{*}{4} & College student & 1. Meet the requirements of taking the exam on the learning process \\
\hline & & 2. Conduct exams to meet CPK graduation requirements \\
\hline & & 3. Receive test results every CPK taken \\
\hline & & 4. Receive the results of the assessment on-line after the end of the semester \\
\hline & & 5. Receive card of study result at the end of semester, on every semester \\
\hline \multirow[t]{4}{*}{5} & Administration & 1. Submit form for CPK implementation \\
\hline & & 2. Preparing final semester exam results through Study Results Card \\
\hline & & 3. Doing documentation about the exam, CPK from the lecturer \\
\hline & & 4. Delivering Study Results Card / KHS to the students \\
\hline \multirow[t]{2}{*}{6} & Academic HRD & 1. Do archiving the value of each course \\
\hline & Bureau & 2. Conducting a review of the students' grades \\
\hline
\end{tabular}




\subsubsection{SOP Model of Learning STAI}

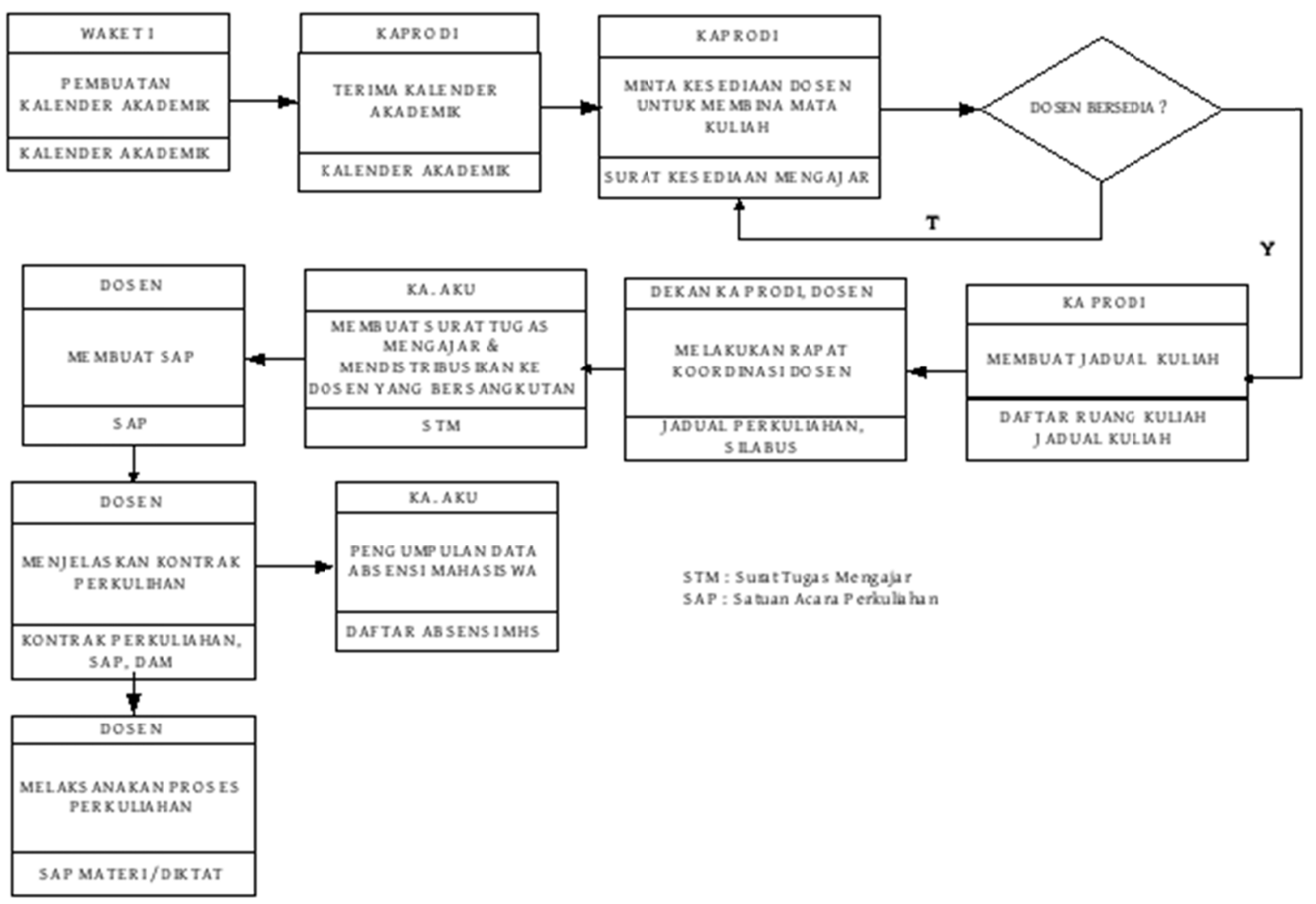

Table 12. Work instruction exam middle semester / final exam semester of STAI

\begin{tabular}{|c|c|c|c|}
\hline \multicolumn{2}{|c|}{ HIGH SCHOOL LOGO } & Type of activity & Approved by \\
\hline Date set & $\begin{array}{l}\text { Created by the Head of } \\
\text { Study Program }\end{array}$ & $\begin{array}{c}\text { Conducting UTS / UAS } \\
\text { activities }\end{array}$ & Vice Chairman 1 \\
\hline
\end{tabular}

Aim: This procedure aims to ensure the implementation of the Middle Exam Semester (UTS) as well as the Final Exam Semester run smoothly.

Scope: This procedure is valid from the start of the Mid Semester Exam preparation session, and the final exam of Semester, until the acceptance of the Middle Semester Exam and Semester Final Exam from the lecturer

Table 13

\begin{tabular}{ccl}
\hline No. & Executor & \multicolumn{1}{c}{ Activities } \\
\hline 1 & Vice Chairman 1 & 1. Setting a lecture calendar \\
& & 2. Establish the Middle Semester Exam schedule and Final Exam Semester \\
& 3. Conducting preparatory meetings of Middle Semester Exam and Final \\
& & Exam Semester \\
& & 1. Determine your Exam financing budget \\
& 2. Coordinate with Vice-Chair 1 on the exam fund \\
& & 1. Attend an Exam meeting invitation \\
& & 2. Preparing for the exam \\
& & 3. Submit exam questions on administration to duplicate \\
& & 4. Exam oversight \\
& 5. Conduct assessment of exam results \\
& 6. Submit the results of the Trial to the Head of AKU (General Finance
\end{tabular}




\begin{tabular}{ll}
\hline \multirow{3}{*}{ College student } & Administration) \\
& 1. Meet the requirements of the Exam \\
& 2. Take the exam number \\
& 3. Conducting mid semester exam / end of semester \\
& 4. Accept the test results \\
1. Prepare the number of Participants Exam Middle Semester and Final Exam \\
Semester \\
2. Collect exam questions from lecturers \\
3. Doubling exam questions \\
4. Distributing exam questions according to the number of participants and \\
the number of courses \\
Performs archiving of Exam result values
\end{tabular}

From the SOP Model example it shows a definite path in doing the activities, and becomes clearer and measurable when equipped with Work Instructions.

\section{Conclusion}

EMI and EMIS, conducted by several universities or high schools as a form of evaluation of service quality standards, and based on the results of EMI and EMIS achievement shows the effect on student satisfaction as stakeholders. Satisfaction can provide benefits between the manager and the service user is good communication, and can be sustainable, and to provide quality assurance on the service, then set SOP model that is based on work instructions.

\section{Suggestion}

1). For Higher Education managers, should EMI and EMIS

2). Stakeholder satisfaction should be considered

3). EMI and EMIS achievement results should be given attention, because it is an illustration in the implementation of quality assurance

4). In determining the SOP Model should be equipped with work instructions, because it can provide clarity for stakeholders in doing a goal.

\section{References}

Agusty Ferdinand. (2002). Structural Equation Modeling in Management Research. Model Application Books in Research. Lecturer of Undip Faculty of Economics.

Bambang, P., \& Lina, M. (2012). Quantitative Research Methods. Jakarta: Rajawali Pers.

Berry, Leonard L. (1995). On Great Service. New York: The Free Press.

Bovee, Courtland L., Michael J. Houston, \& John V. Thill. (1995). Marketing (2nd ed.). New York: Mc Graw-Hill.

Desser, G. (2004). Human Resource Management. Jakarta: PT. Index, Gramedi group.

Gazpers, V. (2003). Total Quality Management. Jakarta: Gramedia Pustaka Utama.

Juram, J, M. (1995). Designing Quality. Jakarta: PT Pustaka Binaman Pressindo.

Kotler, Philip Dan Kevin Lane Keller. (2007). Marketing Management (12th ed.).Index: Jakarta.

Law on Teachers and Lecturers. (2005). No. 14.

Lovelock, Christopher. (1994). Product Plus. New York, McGraw-Hill, Inc.

Moleong, Lexy, J. (2006). Qualitative Research Methodology. Bandung: Teens Rosdakarya.

Sugiyono. (2010). Statistics for Research. Bandung: Alfabeta.

Tjiptono, Fandy. (1995). Marketing Strategy. Jogyakarta, Andi Offset.

\section{Copyrights}

Copyright for this article is retained by the author(s), with first publication rights granted to the journal.

This is an open-access article distributed under the terms and conditions of the Creative Commons Attribution license (http://creativecommons.org/licenses/by/4.0/). 